\title{
Teaching NeuroImages: Radiographic evolution in an adult case of acute necrotizing encephalopathy
}

Wenzhao Liang, MD,* Yankun Shao, MD, * Yang Cui, MMed, Shuai Wu, MMed, Feng Lu, MMed, Jinting He, MD, Yingying Wang, MMed, Xiaobin Han, BM, Jing Mang, MD, and Zhongxin Xu, MD

Neurology ${ }^{\circledR}$ 2018;91:e490-e491. doi:10.1212/WNL.0000000000005909

\section{Correspondence}

Dr. Mang

mangjing@jlu.edu.cn or

Dr. Xu

xuzhongxin999@aliyun.com

Figure 1 Radiographic evolution on T1- and T2-weighted images

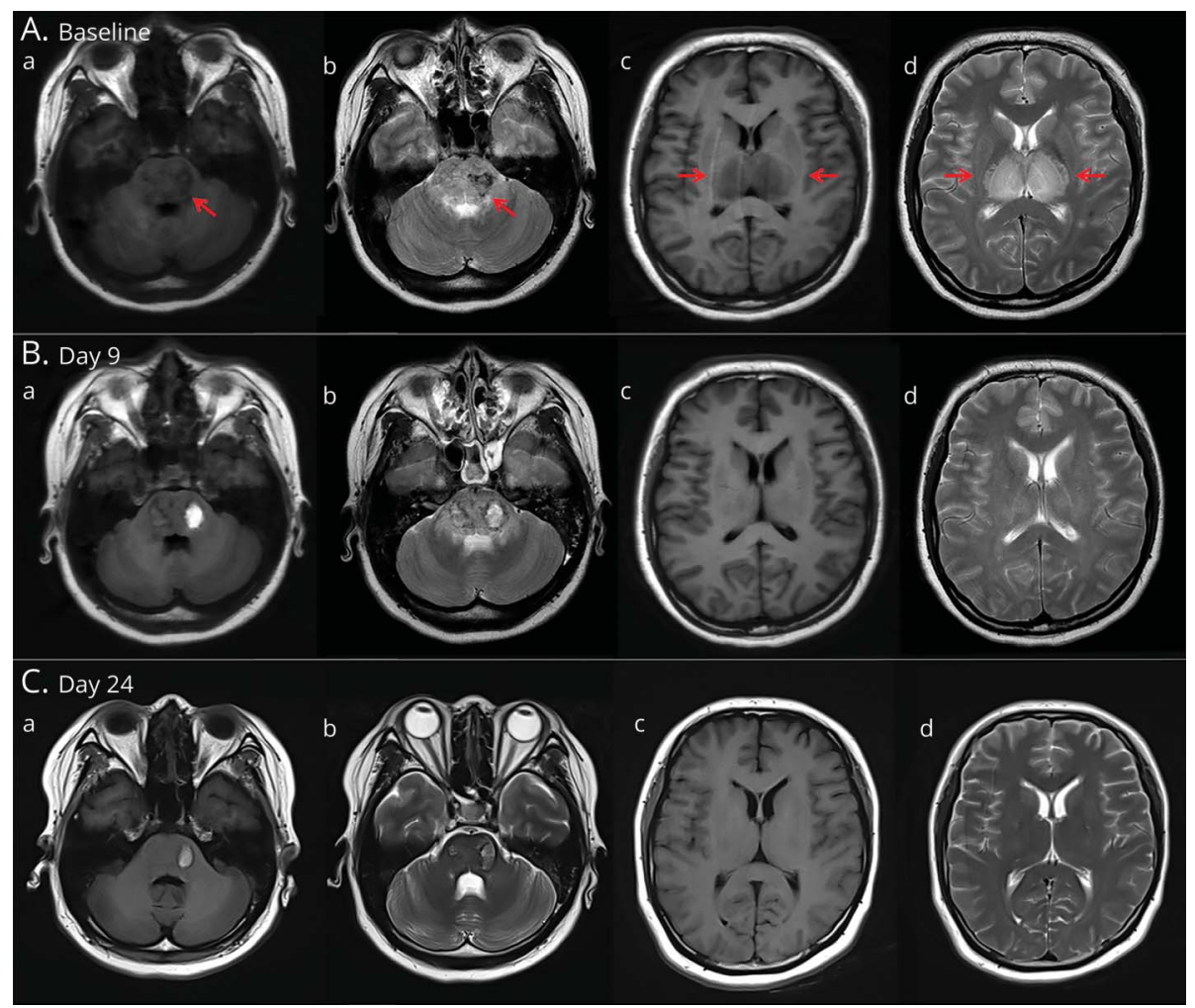

(A) Initial MRI shows hypointense T1 and T2 signals in the pons (A.a, A.b) and hypointense $\mathrm{T} 1$ and hyperintense $\mathrm{T} 2$ signals in the bilateral thalami (A.c, A.d), and demonstrates hemorrhagic necrosis. $(B, C)$ Repeated MRI reveals a gradual reduction of the pontine (B.a and C.a: T1, B.b and C.b: T2) and thalamic lesions (B.c and C.C: T1, B.d and C.d: T2).

A healthy 37-year-old woman developed delirium and was comatose on admission after a 3-day history of chills, fever, and myalgias. Neuroimaging showed lesions affecting bilateral thalami and pons (figures 1 and 2) and normal venous sinuses. Laboratory tests detected elevated serum aminotransferases, increased CSF protein, and no specific virus (tables e-1-e-3, links.lww.com/WNL/A597). She gradually recovered consciousness in 4 days, maintained left-sided 1/5 plegia and slurred speech, and was discharged 28 days later (NIH Stroke Scale score 2).

\section{MORE ONLINE}

\section{$\rightarrow$ Teaching slides}

links.lww.com/WNL/A598

*These authors contributed equally to this work.

From the Departments of Neurology (W.L., Y.S., Y.C., J.H., Y.W., X.H., J.M., Z.X.) and Radiology (S.W., F.L.), China-Japan Union Hospital of Jilin University, Jilin Sheng, China. Go to Neurology.org/N for full disclosures. Funding information and disclosures deemed relevant by the authors, if any, are provided at the end of the article. 


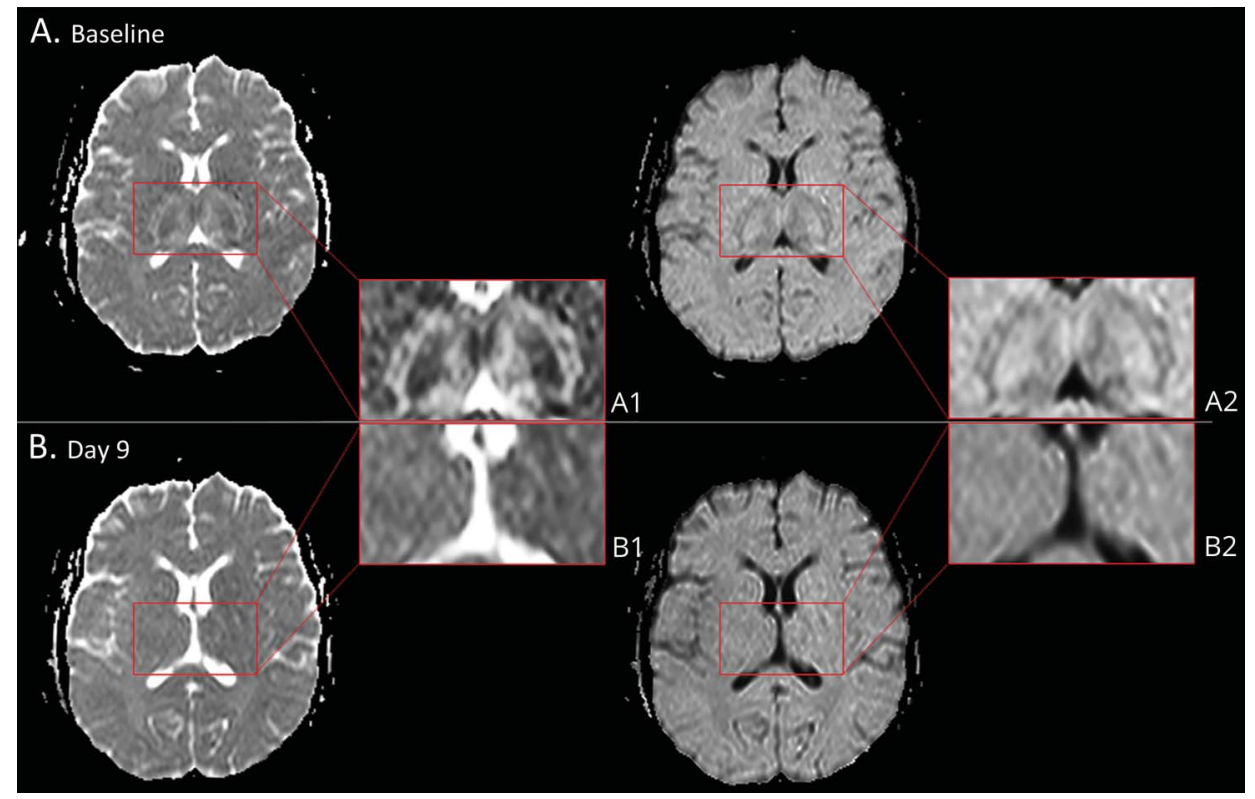

(A) At admission, ADC and DWI show target-like lesions and edema in the bilateral thalami. (B) Day 9, ADC and DWI reveal a regression of the lesions.

Acute necrotizing encephalopathy (ANE) occurs rarely in adult patients. The multifocal, symmetric brain lesions triggered by antecedent infections are the most distinctive features of ANE (figure e-1, links.lww.com/WNL/A596). ${ }^{1,2}$

\section{Author contributions}

Wenzhao Liang: study concept and acquisition of data. Yankun Shao: acquisition of data and patient treatment. Yang Cui: acquisition of data. Shuai Wu: construction of figures. Feng Lu: construction of figures. Jinting He: acquisition of data. Yingying Wang: acquisition of data. Xiaobin Han: patient treatment. Jing Mang: study design and critical revision of the manuscript. Zhongxin Xu: acquisition of data.

\section{Study funding}

No targeted funding reported.

\section{Disclosure}

The authors report no disclosures relevant to the manuscript. Go to Neurology.org/N for full disclosures.

\section{References}

1. Bassuk AG, Burrowes DM, McRae W. Acute necrotizing encephalopathy of childhood with radiographic progression over 10 hours. Neurology 2003;60: 1552-1553.

2. Mizuguchi M. Acute necrotizing encephalopathy of childhood: a novel form of acute encephalopathy prevalent in Japan and Taiwan. Brain Dev 1997;19: $81-92$. 


\section{Neurology}

\section{Teaching NeuroImages: Radiographic evolution in an adult case of acute necrotizing encephalopathy}

Wenzhao Liang, Yankun Shao, Yang Cui, et al.

Neurology 2018;91;e490-e491

DOI 10.1212/WNL.0000000000005909

\section{This information is current as of July 30, 2018}

\section{Updated Information \& Services}

References

Subspecialty Collections

Permissions \& Licensing

Reprints including high resolution figures, can be found at: http://n.neurology.org/content/91/5/e490.full

This article cites 2 articles, 1 of which you can access for free at: http://n.neurology.org/content/91/5/e490.full\#ref-list-1

This article, along with others on similar topics, appears in the following collection(s):

Encephalitis

http://n.neurology.org/cgi/collection/encephalitis

MRI

http://n.neurology.org/cgi/collection/mri

Information about reproducing this article in parts (figures,tables) or in its entirety can be found online at:

http://www.neurology.org/about/about_the_journal\#permissions

Information about ordering reprints can be found online:

http://n.neurology.org/subscribers/advertise

Neurology ${ }^{\circledR}$ is the official journal of the American Academy of Neurology. Published continuously since 1951, it is now a weekly with 48 issues per year. Copyright @ 2018 American Academy of Neurology. All rights reserved. Print ISSN: 0028-3878. Online ISSN: 1526-632X.

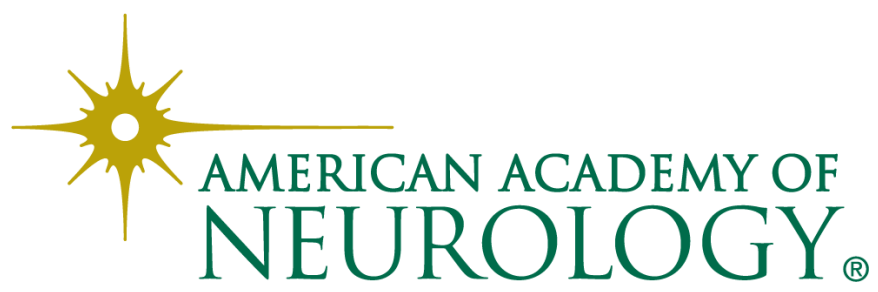

